\title{
Nanomaterials in dentistry - potential capabilities, applications, limitations and hazards. Review of the literature. Part 2
}

\author{
Nanomateriały w stomatologii - potencjalne możliwości, zastosowanie, ograniczenia \\ i niebezpieczeństwa. Przegląd piśmiennictwa. Część II
}

\author{
Bartosz Dalewski ${ }^{\boxplus}$, Ewa Sobolewska', Bogumiła Frączak¹ \\ ${ }^{1}$ Pomorski Uniwersytet Medyczny w Szczecinie, Katedra i Zakład Protetyki Stomatologicznej, al. Powstańców Wlkp. 72, 70-111 Szczecin \\ Pomeranian Medical University in Szczecin, Chair and Department of Dental Prosthetics \\ $\triangle$ bartosz.dalewski@pum.edu.pl
}

\begin{abstract}
Introduction: Nanotechnology has been established in dental specialities as a novel methodology for developing materials with enhanced physical properties and antimicrobial potential. In this review, we discuss the current progress, prospects, and potential future applications of functional nanoparticles contained in nanomaterials as useful strategies for refining their ability to resist occlusal forces, as well as oral biofilm management. We also provide an overview of the suggested antimicrobial mechanisms for these nanoparticles.

The purpose of this study was to use an evidence-based approach to assess the possible applications of nanomaterials in various fields in contemporary and potential future dentistry.
\end{abstract}

Methods: A comprehensive search of Medline (PubMed) and the ISI Web of Science database was carried out.

Results: Nanomaterials have significant potential for decreasing bacterial biofilm accumulation, inhibiting the demineralization process, remineralizing dental tissues, and combating cariesrelated bacteria. However, their ability to withstand intraoral forces needs to be further improved.

Conclusions: The results reviewed in this work present a bright outlook and open doors for future clinical studies that will allow admission of the therapeutic value of nanotechnology-based dental materials.

Keywords: acrylic resins; graphene; nanocomposites; nanoparticles; silver.

\begin{abstract}
ABSTRAKT
Wstęp: Nanotechnologia na dobre zagościła w poszczególnych specjalizacjach stomatologicznych jako nowatorska metodologicznie idea wdrażania materiałów o zarówno podwyższonych parametrach mechanicznych, jak i posiadających olbrzymi potencjał antymikrobiologiczny. Praca przedstawia obecny postęp perspektywy, potencjalne przyszłe zastosowania oraz ograniczenia nanocząstek $w$ aspekcie wytrzymałości określonych materiałów stomatologicznych oraz ich odporności na biofilm jamy ustnej.

Celem niniejszego przeglądu piśmiennictwa była rzetelna analiza potencjalnych korzyści i zagrożeń wynikających z zastosowania nanocząsteczek w jamie ustnej w świetle medycyny opartej na dowodach, zarówno obecnie, jak i w niedalekiej przyszłości.
\end{abstract}

Metody: Przeszukano bazy danych Medline (PubMed) i ISI Web of Science.

Wyniki: Nanomateriały posiadają znaczący potencjał hamujący agregację płytki bakteryjnej, mogą przeciwdziałać procesom demineralizacji, remineralizować tkanki zębów oraz zwalczać określone typy drobnoustrojów. Jednakże ich zdolność do znoszenia dodatkowych obciążeń, a tym samym zwiększania wytrzymałości mechanicznej, nie znajduje potwierdzenia w obecnie dostępnym piśmiennictwie i wymaga dalszych badań. Również odległe skutki ich użycia, z potencjalną toksycznością włącznie, nakazują zachować dalece idącą ostrożność w stosowaniu. Słowa kluczowe: akryl; grafen; nanokompozyt; kompozy ty; nanocząsteczki; srebro.

\section{ENDODONTICS}

Mineral trioxide aggregates (MTAs) have been extensively used in all fields of endodontics. One of the major weaknesses of this material is the long setting time. Mineral trioxide aggregate is primarily composed of type 1 Portland cement and bismuth oxide. In the cement, nanoscale $\mathrm{SiO}_{2}$ acts as a filler, improving the microstructure and accelerating the hydration process. In a study by Akbari et al. two

concentrations ( $8 \%$ and $10 \%$ ) of nano- $\mathrm{SiO}_{2}$ were combined with white MTA powder. After mixing with water, the setting time and compressive and flexural strengths were measured and compared to those of pure MTA. The addition of nano- $\mathrm{SiO}_{2}$ to MTA accelerated the hydration process significantly, reduced the setting time, and had no adverse effect on the compressive and flexural strengths of MTA. However, there was no significant difference noticed between $8 \%$ and $10 \%$ nano- $\mathrm{SiO}_{2}$ concentrations [1]. 
In another study, the effect of storage $\mathrm{pH}$ on the solubility of white mineral trioxide aggregates (WMTAs), bioaggregates, and nano-WMTA cements was compared. The results suggested that the solubility of all the tested cements could be jeopardised in an acidic environment, which might affect their sealing characteristics in a clinical situation. However, nano-WMTA cement, because of its small particles and different additives, was capable of producing lower porosity in the set material, which resulted in increased resistance to acidic environments [2].

The sealing ability of a new experimental nano-ZOE-based sealer was also investigated. Three types of nano-ZOE-based sealers (calcined at temperatures of 500,600 , and $700^{\circ} \mathrm{C}$ ) and two other commercially available sealers $\mathrm{AH}_{2} 6$ and microsized zinc oxide eugenol sealer) were studied. Microleakage in the AH26 group was significantly greater than that in the three groups of ZnO nanoparticles at all three evaluation intervals. In addition, the apical microleakage of the $\mathrm{ZnO}$ micropowders was significantly more than that of all the other materials. However, the sealing ability of the $\mathrm{ZnO}$ nanopowder sealers did not differ significantly. The results of this study indicate that the synthesised $\mathrm{ZnO}$ nanopowder sealers are suitable for use as nanosealers in root canal therapy to prevent leakage. However, further studies should be performed to verify their safety [3]

The use of metal oxide nanoparticles has attracted significant attention mostly because of their promising antimicrobial activity, along with their biocompatibility with mammalian cells. The in vitro and ex vivo antimicrobial efficiency of nano-magnesium oxide (nano-MgO) aqueous solutions against endodontic pathogens was investigated. The cytotoxicity of nano-MgO at different concentrations was assessed using the lactate dehydrogenase cytotoxicity assay (LDH assay). The antimicrobial effectiveness of nano-MgO solutions (at several concentrations), sodium hypochlorite ( $\mathrm{NaOCl}$ ), and chlorhexidine (CHX) gluconate against Staphylococcus aureus, Enterococcus faecalis ( $E$. faecalis), and C. albicans were collated using the direct contact method. An ex vivo model of decoronated and experimentally infected human teeth was utilised to compare the efficiency of a nano- $\mathrm{MgO}(5 \mathrm{mg} / \mathrm{L})$ solution to that of $\mathrm{NaOCl}$ (5.25\%) in eliminating E. faecalis. There was no statistically significant difference reported between nano-MgO solutions (10 and $5 \mathrm{mg} / \mathrm{L}$ ), $5.25 \% \mathrm{NaOCl}$, and $2 \% \mathrm{CHX}$ gluconate in terms of the time required to inhibit the growth of the tested pathogens ( $p>0.05)$. In the ex vivo model of infected human teeth $6 \mathrm{~h}$ post-irrigation, there was no statistically significant difference between the CFU per millilitre of nano-MgO ( $5 \mathrm{mg} / \mathrm{L})$ and that of $\mathrm{NaOCl}$ (5.25\%)-treated teeth (5-6 log scale reduction). However, the nano-Mg0 group showed a significant decrease in the value of CFU per millilitre ( 7 log scale) $24 \mathrm{~h}$ post-irrigation ( $p<0.05$ ). At other testing times, namely, 24, 48, 72, and $168 \mathrm{~h}$, the levels of CFU per millilitre were significantly lower in the nano-MgO group (2-3 log scale difference) as compared to the $\mathrm{NaOCl}$ group, indicating the long-term antibacterial activity of nano-MgO ( $\mathrm{p}<0.05)$. At 72 and $168 \mathrm{~h}$ post-irrigation, no detectable bacterial growth was observed in the nano-MgO group. Nano-MgO aqueous solutions exhibited promising antimicrobial activities, both in vitro and ex vivo, with marginal toxicity. As compared to $\mathrm{NaOCl}$ (5.25\%), nano- $\mathrm{MgO}$ (5 mg/L) exhibits statistically significant long-term efficiency in eliminating $E$. faecalis from the root canal system. After additional investigations, nano-MgO could be considered a new root canal irrigant [4].

\section{PROSTHETIC DENTISTRY}

Alginate nanomaterials could be used as antimicrobial agents. A significant improvement in the relative bioavailability of confirmed encapsulated drugs has been observed. In addition, these materials appear to be potentially useful for the intermittent treatment of tuberculosis [5].

Alginate powders can be mixed with water containing Ag hydrosol to create an impression material that exhibits antimicrobial activity, which reduces microbial cross contamination by bacteria, yeasts, other fungi, and viruses from the contaminated impression to the casts. Antimicrobial root canal sealers/cements containing dilute Ag hydrosols are effective in the permanent obturation of root canals following the removal of the infected pulp and the placement of medicaments [6].

A variety of permanent dental cements, including epoxy resin cements, glass ionomers, and resin-modified glass ionomer cements (used in fixed dentures) can be impregnated with Ag hydrosol. Any number of commonly used permanent dental cements can also be readily combined with the Ag hydrosol solution. By adding Ag hydrosol to these cements, a continuous dynamic antimicrobial bacteriostatic environment capable of decreasing bacterial concentration can be furnished, and thus post-operative inflammation, infection, and sensitivity can be decreased, which is remarkably important with vital teeth [7]. Novel polyquaternary ammonium salt-containing antibacterial glass-ionomer cements have also been developed. All the polyquaternary ammonium salt-containing cements exhibited significant antibacterial activity, accompanied by a reduction of initial compressive strength. Furthermore, it was concluded that the experimental cement is a clinically attractive dental restorative owing to its high mechanical strength and antibacterial functionality [8].

\section{DENTURE STOMATITIS}

Denture stomatitis is a frequent pathology in patients using removable dentures. The etiological factors of this disease primarily include infection with C. albicans, improper hygiene of the oral cavity, and prolonged use of dental prosthesis [9].

The inhibition of $C$. albicans on denture resins can play a significant role in preventing denture stomatitis. The safety of a new dental material with antifungal properties was analysed by Acosta-Torres et al. The results showed that PMMA-Ag nanoparticle discs significantly reduced the adherence of C. albicans and did not affect metabolism or proliferation. They also appeared to prevent genotoxic damage to the cells. The authors also claim to have developed a new biocompatible antifungal PMMA denture-based material [8, 9]. 
Poly(methyl methacrylate) is widely used for the fabrication of removable dentures. Although NAg have been added to PMMA because of their antimicrobial properties, their effect on the mechanical properties of PMMA is unknown. Ghaffari and Hamedi-rad investigated the effect of NAg on the tensile strength of PMMA. Twelve specimens were prepared and divided into two groups. Group 1 comprised PMMA without NAg, whereas group 2 comprised PMMA mixed with $5 \mathrm{wt} \% \mathrm{NAg}$. The mean tensile strength of PMMA in group 2 was considerably lower than that in group 1, indicating that the incorporation of NAg resulted in a significant decrease in tensile strength [9].

In four separate studies, Lee and Tsao [10], Lee et al. [11] Boldyryeva et al. [12], and Casemiro et al. [13] added Ag-zinc antimicrobial zeolites in low percentages to PMMA. This material can also be used as a valuable alternative to reduce microbial contamination of tissue conditioners, acrylic resin denture bases, and acrylic base plates of removable orthodontic appliances. Zeolites are aluminium silicate crystalline structures. The addition of $2.5 \%$ zeolites to PMMA resulted in decreased flexural and impact strength [11,14]. Ag zeolite nanoparticles have been incorporated into mouth rinses and toothpastes [13]. Currently, powdered zinc citrate or acetate are also being incorporated to control the formation of dental plaque. Powdered titanium dioxide is also commonly used as a whitener in toothpastes [15]. Moreover, nanoparticles can be used successfully in other materials, including hydrogels $[14,15,16]$. Chladek et al. presented a method for incorporating NAg into chemically cured silicone soft-liner materials. The antifungal efficacy (AFE) of the resulting composites containing 10-200 ppm NAg particles was $16.3-52.5 \%$. This level of AFE is capable of preventing colonisation of $C$. albicans on soft denture linings $[17,18,19]$. Monteiro et al. combined the above method with nystatin (NYT) and chlorhexidine digluconate (CHG). The data indicated that NAg combined with either NYT or CHG exhibited synergistic antibiofilm activity that was dependent on the species and on the drug concentrations used. Scanning electron microscope (SEM) images showed that some drug combinations were able to disrupt the Candida biofilm [20]. Nam et al. confirmed these results. In their study, a modified denture base acrylic combined with NAg exhibited antifungal properties and acted as a latent antifungal material with low release of Ag ions. However, the colour stability was inadequate and still needed to be improved [21,22].

Organic-inorganic hybrid materials such as polyhedral oligomeric silsesquioxanes (POSS) are capable of improving the mechanical properties of the methacrylate-based composites and resins used in dentistry. Wang et al. investigated nanocomposites of methacryl isobutyl POSS [MI-POSS (bearing only one methacrylate functional group)] and methacryl POSS [MA-POSS (bearing eight methacrylate functional groups)] to determine the effect of the structures on the properties of dental resins. Monofunctional POSS exhibited a strong tendency towards aggregation and crystallisation, whereas multifunctional POSS showed higher miscibility with the dimethacrylate monomer. The mechanical properties and wear resistance decreased with increasing amounts of MI-POSS, indicating that MI-POSS agglomerates act as mechanically weak points in dental resins. The addition of small amounts of MA-POSS improved the mechanical and shrinkage properties. However, samples with a higher MA-POSS concentration showed lower flexural strength and flexural modulus, indicating that there is a limited range in which the reinforcement properties of MA-POSS can operate. This concentration dependence is attributed to phase separation at higher concentrations of POSS, which affects the structural integrity and thus the mechanical and shrinkage properties of the dental resin. These results show that resin with $3 \%$ MA-POSS is a promising candidate for resin-based dental materials [23].

\section{RESISTANCE TO INTRAORAL FORCES}

Melo et al. [24] incorporated amorphous calcium phosphate (NACP) and NAg into a bonding agent for the first time, yielding a material with potent antibacterial activity while maintaining a strong dentin bond strength. The rationale for adding NACP and NAg was to merge the Ca and $\mathrm{PO}_{4}{ }^{3-}$ ions from NACP with the antibacterial activity of NAg to inhibit biofilm formation and caries. The addition of $0.1 \%$ NAg and 10-40\% NACP did not compromise the dentin bond strength; NACP was previously shown to exhibit high levels of $\mathrm{Ca}^{2+}$ and $\mathrm{PO}_{4}{ }^{3-}$ ion release, which could remineralize tooth tissue. The study by Melo et al. showed that NACP presented little antibacterial activity. The antibacterial effect was provided by NAg, which reduced the total number of microorganisms. Metabolic activity and lactic acid production were also greatly reduced. Antibacterial and NACP-containing bonding agents may help inhibit residual bacteria in the tooth cavity, hinder invading bacteria along the margins, and remineralize lesions. The unique method for simultaneously incorporating NACP, a remineralizing agent, and NAg, an antibacterial agent, in the same adhesive may have extensive applicability in other bonding systems, cements, and novel dental adhesives [25].

Zhang et al. investigated the hybrid effects of $\mathrm{ZrO}_{2}$ nanoparticles (nano- $\mathrm{ZrO}_{2}$ ) and aluminium borate whiskers (ABWs) on the flexural strength and surface hardness of PMMA, a denture base resin. Both nano- $\mathrm{ZrO}_{2}$ and $\mathrm{ABW}$ were modified by a silane-coupling agent (Z6030) before being mixed with PMMA. Various amounts of silanized nano- $\mathrm{ZrO}_{2}$ and $\mathrm{ABW}$ s were combined with PMMA to prepare $\mathrm{ZrO}_{2}$-ABW/PMMA composites. The flexural strength and surface hardness of the composites were evaluated using the three-point bending test and Vickers hardness test, respectively. Fractured surfaces were observed by SEM. The mechanical behaviours of the silanized $\mathrm{ZrO}_{2}-\mathrm{ABW} /$ PMMA composites were significantly improved. The flexural strength reached a maximum value of 108.01 $\pm 5.54 \mathrm{MPa}$ when $2 \mathrm{wt} \%$ of nano- $\mathrm{ZrO}_{2}$ was mixed with $\mathrm{ABWs}$ at a $\mathrm{ZrO}_{2} / \mathrm{ABW}$ ratio of $1: 2$, amounting to a $52 \%$ increase as compared to pure PMMA. The surface hardness reached a maximum value of $22.50 \pm 0.86 \mathrm{MPa}$ when $3 \mathrm{wt} \%$ of nano- $\mathrm{ZrO}_{2}$ was mixed with $\mathrm{ABW}$ at the same $\mathrm{ZrO}_{2} / \mathrm{ABW}$ ratio, which was an increase of $27 \%$ as compared to pure PMMA [26]. 
A glass ionomer-containing respectively $3 \mathrm{wt} \%$ and $5 \mathrm{wt} \%$ $\mathrm{TiO}_{2}$ nanoparticles showed improved fracture toughness, flexural strength, and compressive strength as compared to the unmodified glass ionomer. However, a glass ionomer-containing $7 \mathrm{wt} \% \mathrm{TiO}_{2}$ nanoparticles exhibited a decrease in mechanical properties. In particular, the glass ionomer-containing the above-mentioned $5 \mathrm{wt} \%$ and $7 \mathrm{wt} \% \mathrm{TiO}_{2}$ nanoparticles showed reduced surface microhardness. The setting time of the glass ionomer-containing $\mathrm{TiO}_{2}$ nanoparticles was satisfactory and met the criteria for water-based cements. The addition of $\mathrm{TiO}_{2}$ nanoparticles to conventional glass ionomers did not compromise their bond strength as a result of dentine or fluoride release of the glass ionomer. The glass ionomer-containing $\mathrm{TiO}_{2}$ nanoparticles also exhibited improved antibacterial activity against $S$. mutans as compared to unmodified glass ionomers [27].

Considering the above factors, investigations aimed at developing modified acrylic materials with improved resistance properties have been conducted. One of the methods for improving the resistance properties of acrylic materials is the addition of a filler (bentonite) to the polymer. The production of a composite by the addition of a filler is expected to enable the production of a thinner, lightweight dental prosthesis that would be more comfortable for the user. To achieve the latter effect, the filler should be dispersed in the polymer matrix to the maximum possible extent. Composites are materials obtained through the combination of at least two component materials with different characteristics and forms. A composite has characteristics that reflect the properties of its components according to their volume ratio [28].

The term 'nanocomposites' denotes a material consisting of two phases, with one phase dispersed in the other on a nanometre level $\left(10^{9} \mathrm{~m}\right)$. In most cases the size of the nanocomposite structure falls within $100 \mathrm{~nm}$, with sizes up to several hundred nanometres occurring rather rarely [29]. The matrix in the polymer nanocomposites can be either thermoplasticbased or thermally cured. In addition to the polymer, in most cases, non-organic substances mainly consisting of various types of laminar silicate or silica are also present. Fullerenes, metals, and other non-organic compounds may also be present. Polymer nanocomposites are formed through the modification of conventional synthetic materials. The introduction of relatively small amounts (several parts by weight) of a component crushed to nanometre-scale particle sizes (anisotropic nanoparticles of high shaping factor) to the matrix significantly influences the features of the nanocomposite. The polymer nanocomposites usually contain from 1 up to 5 parts by weight (max. up to 10 parts by weight). After the addition of the nanofiller, the composite shows considerable improvement in tensile strength and increased Young's modulus, as well as improved compressive strength.

Laminate silicates such as montmorillonite constitute the most important group of nanofillers. The term stands for natural clay minerals and synthetic laminars such as magadite, laponite, and fluorohectorite. Montmorillonites are the key components of rocks known as bentonites. Both natural and synthetic laminars are used as nanofillers in nanocomposites. The distinctive feature of montmorillonite is its sorption capability for certain cations and their retention after exchange, which enables the modification of the mineral. The various methods for producing PMMA-bentonite nanocomposites can be divided into two categories. The first group is based on polymerisation in mass or polymerisation in solvent, whereas the other includes intercalation in an alloy [30]. The methyl methacrylate (MMA) polymerisation reaction is carried out in the presence of dispergated and modified bentonite. The monomer penetrates the mineral, forming a pack, causes reinforcement of the pack, and is then separated from the mineral. The polymer chains, which expand during the polymerisation process, are stuck between the silicate layers, trapping the montmorillonite and allowing the layers to separate. As a result, a filler-containing composite with a high dispersion degree is obtained [31]. However, Spychaj et al. and Sobolewska et al. described an attempt to modify a prosthetic material, namely Vertex R.S., with hydrophobic bentonite/montmorillonite in order to improve the mechanical strength of dentures. Hydrophobized bentonite was dispersed in MMA by sonication and then polymerised by the solution-precipitation method. The mechanical and optical properties of the polymer composites containing the modified montmorillonite were evaluated. However, the mechanical properties of the denture were not improved. Their experimental results on bending strength and impact resistance suggest that the addition of a filler, regardless of the filler type or method, reduces the mechanical properties of PMMA [32, 33].

Other authors have reported attempts to reinforce a prosthetic material by using material nets, glass, fabric, nylon fabric, carbon fabric, aramide fabric, and even Kevlar [34, 35, 36, $37,38,39,40]$. Although carbon-graphite reinforcements in particular appear to be promising $[34,35,36]$, more in vivo studies are required [37].

Therefore, the use of nanoparticles might lead to improvements in mechanical properties such as wear resistance and surface hardness of dental restorative materials $[40,41]$. The major difference between nanometric and micrometric particles is that nanoparticles have a significantly larger specific surface area, which facilitates the transfer of loads from the polymer matrix to the nanoparticles $[42,43,44]$. Consequently, nanoparticle-reinforced hybrid systems present increased stiffness and improved resistance to wear [42].

Protopapa et al. conducted a study on the possibility of reinforcing PMMA resin with nanodiamonds (NDs) for fixed interim dentures. The fracture toughness, impact strength, and dynamic thermomechanical properties of a series of PMMA-ND nanocomposites with various amounts of NDs were evaluated. Although the fracture toughness increased as the ND percentage increased up to $0.38 \mathrm{wt} \%$, higher amounts of NDs resulted in a decrease in the fracture toughness. The impact strength and Young's modulus also increased with increasing amounts of NDs, indicating the reinforcing effect of NDs. Dynamic mechanical properties were also modified. By increasing the ND content, the storage modulus was improved, whereas the glass transition took place at higher temperatures. 
Under the limitations of this study, it can be suggested that reinforcing PMMA with ND nanoparticles, especially at low concentrations, may improve the general performance of fixed interim restorations [45].

\section{GRAPHENE}

Carbon nanotubes (CNTs) are carbon atoms arranged in a crystalline graphene lattice with a tubular morphology. Carbon nanotubes display high tensile strength, exhibit unique electrical properties, are durable, and can be functionalized. These properties allow their application as structural materials in electronics applications, as heating elements, in batteries, in the production of stain-resistant cloth, for bone grafting and dental implants, and for directed drug delivery. On the other hand, carbon nanofibres are strong, flexible fibres that are presently used to manufacture composite materials [46]. In the future, fabricating a graphene-acrylic composite would allow temperature sensing through the denture base plate due to the significant increase in thermal conductivity by the addition of graphene. The use of additional coatings would amplify this effect and secure the denture against the ingress of both microbial infiltration and residual monomer secretion.

However, the results of studies on rodents collectively showed that regardless of the method by which CNTs were synthesised and the types and amounts of metals they contained, the use of CNTs resulted in inflammation. Epithelioid granulomas (microscopic nodules), fibrosis, and biochemical/ toxicological changes in the lungs were detected. Comparative toxicity studies, where mice are given even weights of the test materials, showed that SWCNTs were more noxious than quartz, which is considered a serious occupational health risk material if chronically inhaled. On the other hand, ultrafine carbon black was shown to generate minimal lung response [47]. Graphene was further shown to produce respiratory function impairments, decrease bacterial clearance after bacterial inoculation, damage the mitochondrial DNA in the aorta, increase the percent of aortic plaque, and induce atherosclerotic lesions in the brachiocephalic artery of the heart. It is hypothesised that exposure to combustion-generated MWCNTs may play a significant role in air pollution-related cardiopulmonary disorders. Therefore, CNTs from manufactured as well as combustion sources in the environment could have adverse effects on human health $[48,49]$.

However, with increasing attention to the use of graphene and its derivatives in the field of biomedicine, systematic evaluation of their potential risks and their effect on biological systems has become essential. Feng and Li conducted studies on how surface coatings affect the cytotoxicity and extracellular biodegradation behaviours of graphene oxide (GO) and its derivatives [50]. Although pristine GO could induce significant toxicity to macrophages, coating these two-dimensional nanomaterials with biocompatible macromolecules such as polyethylene glycol (PEG) or bovine serum albumin (BSA) could greatly attenuate their toxicity, as independently evidenced by several different assay approaches. On the other hand, although GO can be gradually degraded through enzymeinduced oxidation by horseradish peroxidase (HRP), both PEG and BSA-coated GO or reduced graphene oxide (RGO) are quite resistant to HRP-induced biodegradation. In order to acquire biocompatible functionalised GO that can still undergo enzymatic degradation, we conjugated PEG with GO via a cleavable disulphide bond, obtaining GO-SS-PEG with insignificant toxicity and considerable degradability. This material is promising for future biomedical applications [51].

Dental caries and periodontal diseases have a close relationship with microbes such as S. mutans, Porphyromonas gingivalis, and Fusobacterium nucleatum. Graphene oxide, which is a derivative of graphene, plays an essential function in many areas, including biology and medicine. In particular, it is recognised as a promising antimicrobial nanomaterial. He et al. focused on the antimicrobial properties of GO vs dental pathogens. Using the 3-(4,5-dimethylthiazol-2-yl)-2,5-diphenyl tetrazolium bromide reduced test, CFU counting, growth curve observation, live/dead fluorescent staining, and confocal laser scanning microscopy, GO nanosheets were observed to be highly effective in inhibiting the growth of dental pathogens. Transmission electron microscopy images showed that the cell walls and membranes of bacteria lost their integrity, and the intracellular contents leaked out after they were treated by GO. Therefore, GO nanosheets would be an effective antibacterial material against dental pathogens, which has potential promising applications in contemporary dentistry [52].

Oral biofilms play a crucial role in the development of dental caries and other periodontal diseases. S. mutans is one of the primary etiological agents causing dental caries. Implant systems are regularly used to replace missing dentition. Oral biofilms accumulate on these implants and are the principal cause of dental implant failure. In one study, the potential of graphene/zinc oxide nanocomposites (GZNCs) against the cariogenic properties of $S$. mutans was investigated, and the antibiofilm behaviour of artificial acrylic teeth surfaces coated with GZNC was examined. Acrylic teeth are a good choice for implants as they are low-cost, have low density, and can resist fracture. Microscopic studies and anti-biofilm assays showed a significant reduction in the formation of biofilms in the presence of GZNC. Graphene/zinc oxide nanocomposite was also found to be nontoxic against HEK-293 (human embryonic kidney cell line). The results indicate the potential of GZNC as an efficient coating agent for dental implants because it efficiently inhibits the formation of $S$. mutans biofilms [53].

Human mesenchymal stem cells (hMSCs) have great potential as cell sources for bone tissue engineering and regeneration. However, the control and induction of their specific differentiation into bone cells remain challenging. Graphene-based nanomaterials are considered attractive candidates for biomedical uses, such as for scaffolds in tissue engineering, substrates for SC differentiation, and components of implantable devices, because of their biocompatible and bioactive properties. Despite the potential biomedical applications of graphene and its derivatives, only limited evidence is available 
on their osteogenic activity. Lee et al. studied the effect of RGOcoated HAP composites on the osteogenic differentiation of hMSCs. The average particle sizes of HAP and RGO were 1270 $\pm 476 \mathrm{~nm}$ and $438 \pm 180 \mathrm{~nm}$, respectively. When coated on HAP particulates, RGO synergistically enhanced the spontaneous osteogenic differentiation of hMSCs without hampering their proliferation. This result was confirmed by determining the alkaline phosphatase activity and mineralization of calcium and phosphate as early- and late-stage markers of osteogenic differentiation. It is suggested that RGO-coated HAP composites can be effectively utilised as dental and orthopaedic bone fillers because these graphene-based particulate materials can potently stimulate the spontaneous differentiation of MSCs and show superior bioactivity and osteoinductive potential [54].

Graphene oxide is a single-layer carbon sheet with a thickness of less than $1 \mathrm{~nm}$. Graphene oxide has good dispersibility owing to surface modification with various functional groups. On the other hand, RGO is fabricated via the reduction of GO and has lower dispersibility. Kanayama et al. examined the bioactivity of GO and RGO films, as well as collagen scaffolds, coated with GO and RGO. The GO and RGO films were fabricated in a culture dish. Some GO films were chemically reduced using either ascorbic acid or sodium hydrosulphite solutions, resulting in the fabrication of RGO films. The biological properties of each film were evaluated by SEM, atomic force microscopy, calcium adsorption tests, and $\mathrm{MC}_{3} \mathrm{~T} 3$-E1 cell seeding. Then, GO and RGO-coated collagen scaffolds were prepared and characterised by SEM and compression tests. Each scaffold was implanted into the subcutaneous tissue on the backs of rats, and the DNA content and cell in-growth areas of the implanted scaffolds were measured 10 days post-surgery. The results showed that GO and RGO possess different biological properties. Calcium adsorption and alkaline phosphatase activity were strongly enhanced by RGO, suggesting that RGO is effective for osteogenic differentiation. The SEM results showed that RGO-modified collagen scaffolds have coarse and irregular surfaces. The compressive strengths of the GO- and RGO-coated scaffolds were approximately 1.7-fold and 2.7-fold higher, respectively, as compared to the uncoated scaffold. The tissue in-growth rate of the RGO-coated scaffolds was $39 \%$ as compared to $20 \%$ in the GO-coated scaffold, and $16 \%$ in the uncoated scaffold. These results suggest that GO and RGO coatings affect the biological properties of the collagen scaffolds, and that RGO-coated scaffolds are more bioactive than GO-coated scaffolds [55].

\section{PERIODONTICS AND IMPLANT DENTISTRY}

Kohgo et al. studied the correlation between the osseointegration of dental implants and tissue-engineered bones using a nanofibre scaffold, PuraMatrix $®$ (PM). The first molar and all the premolars in the mandibular regions of dogs were extracted, and three bone defects were prepared with a trephine bur on both sides of the mandible after 4 weeks. The experimental groups were as follows: (1) PM, (2) PM and dog mesenchymal stem cells - dMSCs, (3) PM, dMSCs, and platelet-rich plasma, and (4) control (defect only). The implants were placed in the prepared areas 8 weeks later and were assessed by histological and histomorphometric analyses (bone-to-implant contact - BIC). The BICs for groups 1, 2, 3, and 4 were 40.77, 50.35, 55.64 , and $30.57 \%$, respectively. The results indicate that PM may be beneficial as a scaffold for bone regeneration around dental implants [56].

In the next study, nano-calcium deficient HAP (n-DA)/ multi-(amino acid) copolymer composite scaffolds were prepared by the injection moulding foaming method using calcium sulphate dihydrate as a foaming agent. The composite scaffolds exhibited pores that remained well interconnected, with pore sizes ranging $100-600 \mu \mathrm{m}$, a porosity of $81 \%$, and a compressive strength of $12 \mathrm{MPa}$. The compressive strength was visibly affected by the porosity. The composite scaffolds slowly degraded in phosphate buffered solution (PBS), and the initial concentration of the composite scaffolds (61 wt\%) decreased after immersion in PBS for 12 weeks. Additionally, the porosity of the composite scaffolds significantly affected their degradability. Moreover, it was found that the composite scaffolds promoted MG-63 cell growth and proliferation and enhanced its alkaline phosphatase activity. The implantation of the scaffolds into the femoral bone of rabbits proved that the composite scaffolds were biocompatible, degradable, and osteoconductive in vivo [57].

Establishing periodontal-like connective tissue attachment is one of the outstanding issues in implant dentistry. Organized nanotopographic titanium surfaces may be used to achieve periodontal-like connective tissue attachment with activation of the fibroblastic function. Hong et al. studied the gingival fibroblastic function and connective tissue attachment on two types of nanotopographic titanium surfaces created by alkali heat $(\mathrm{AH})$ treatment. The surface topography of commercially pure titanium turned discs with or without acid etching or two types of AH treatment were evaluated by SEM. Rat gingival fibroblasts cultured on the discs were evaluated in terms of cellular adhesion, collagen synthesis, and physicochemical binding strength of the deposited collagen on the surfaces. The turned or AH-treated pure titanium mini-implants were placed on the hard palatal plate of rabbits, which were subjected to histological evaluation at 8 weeks post-surgery. The AH-treated surfaces were characterised by numerous wellorganized fine nanospikes with crevasses and nanoholes and a uniform shaggy nanotopography with a sponge-like inner grid. These nanotopographic surfaces exhibited enhanced cellular adhesion and collagen synthesis as compared to the turned or acid-etched surfaces, and the binding strength of the deposited collagen was enhanced sufficiently to withstand experimental overloading and inflammation by the inclusion of collagen fibres into the surface. The AH-treated mini-implants allowed the inclusion of gingival connective tissue into the nanotopographic surface structure, with the direction of the collagen fibre mimicking the periodontal tissue in the transmucosal area. These features were not seen on the turned surface implants. The well-organised nanotopographic titanium surface with nanospikes and pores developed by AH treatment enhanced 
gingival fibroblastic collagen synthesis, and periodontal-like connective tissue attachment was achieved with substantial detachment resistance [58].

\section{ORTHODONTICS}

Nano-Ag ions exhibit antimicrobial effects against a large number of bacterial species, including $S$. mutans and lactobacillus species when added to the adhesives for bonding orthodontic brackets [59]. It has also been proven that NAg ions successfully block an 'entrance' for HIV $[60,61,62]$.

\section{TISSUE-ENGINEERING PERSPECTIVE}

The introduction of nanosized particles has significantly revolutionised tissue engineering. At significantly smaller sizes, these particles have greatly increased surface areas per unit volume and enhanced quantum effects as compared to largesized particles, thus improving the performance of materials [63]. Collective advancements in nanotechnology have enabled the fabrication of innovative scaffolds such as composite nanofibrous scaffolds that simulate the matrix environment in which cells can be accommodated to proliferate and differentiate towards desired lineages [64]. Nanometre-sized fibres can be processed to form highly porous scaffolds that allow easy cell migration and nutrient diffusion. Not only do they provide a large surface area for cell attachment, they also permit the delivery of drugs and growth factors because of better porosity, thereby allowing interactions between cells and the extracellular matrix, as seen during regular tissue development.

Nanofibrous scaffolds that promote functional tissue regeneration can be created by simple coating methods, the blending of polymeric-bioactive molecules, or by surface modification methods. Hydrophilization, electrospinning, and, more recently, electrospun-electrospraying are some of the methods that enable the synthesis of polymeric and composite nano-scaffolds suitable for specific biomedical applications [65].

Creating a controlled microtexture on the implant surfaces via additive surface modification techniques with bioactive nano-HAP has been proven to positively influence guided tissue regeneration. Nanostructured HAP provides a close connection with adjacent tissues and quick resorption characteristics as compared to bulk HAP. It has also been shown to increase the proliferation rate of periodontal ligament cells (PDL), probably by activating the epidermal growth factor and its downstream targets [66]. Modifying the polymer surface with cell adhesive ligands such as an arginine-glycineaspartic acid peptide derived from fibronectin improves cell adhesion and interaction. Huang et al. studied the effect of artificial bioactive nanostructures, namely, branched peptide amphiphile molecules containing arginine-glycine-aspartic acid, on ameloblasts such as cells and enamel organ epithelial cells of mouse embryonic incisors. In both the cell and organ culture models, enhanced cell attachment and proliferation with greater enamel-specific protein expression levels were observed. Introducing cell cleavable groups in polymeric hydrogels also improved cell penetration [67].

\section{NANOPARTICLES FOR DRUG DELIVERY}

Incorporating bioactive molecules into matrix materials enhances regenerative capacities. Nanotechnology has enabled the delivery of growth factors into a scaffold matrix by using vehicles such as agarose beads, alginate gels, collagen sponge, sandwich collagen membranes, hydrogel microspheres, and $\beta$-TCP. These vehicles are released locally into the scaffold at suitable times [68]. Microspheres are drug-encapsulating polymer matrices utilised for the slow and sustained release of the drugs [69]. Low-molecular-weight polymers form porous microspheres that release drugs quickly, whereas high-molecular-weight polymers form dense microspheres that release the drugs gradually. Polylactic-co-glycolic acid microspheres that release vascular endothelial growth factor when delivered into porous scaffolds have provided prolonged release of the growth factor for up to 21 days, resulting in significantly enhanced angiogenesis [70]. Nanotubes used for drug delivery provide greater inner volumes for containing the desired chemical or biochemical species as compared to spheres, and offer distinct inner and outer surfaces that can be differentially functionalised $[71,72]$. Complex drug delivery systems that allow the differential release of multiple bioactive molecules in regulated and sustained doses and provide multiple signalling requirements need to be further investigated. Tissue engineering is one of the recent emerging innovations, and its potential is being widely tested and utilised in numerous medical branches. Biomaterials are essential in tissue regeneration as they serve as porous frameworks over which all the other ingredients for tissue regeneration are laid. Research related to biomaterials has principally focused on the fabrication of scaffolds with optimum physical, chemical, and mechanical properties while including biomolecules and their controlled delivery to promote cell survival and cell-scaffold interactions. With the advent of microscale and nanoscale technologies, it has become possible to design and fabricate scaffolds that are not only large three-dimensional forms but also to provide a three-dimensional micro-environment that supports cell behaviour, tissue function, implantation, and host integration. Although an immense amount of research is still required to regenerate tissues with clinically applicable structures and functionalities, the applicability of stem cells and biomaterial sciences for dental reconstruction cannot be understated and offers a promising future [73, 74].

\section{DISCUSSION}

A significant challenge in nanotechnology is the toxicity-free synthesis of metal nanoparticles. Secrets discovered from nature have led to the development of biomimetic approaches for developing advanced nanomaterials [75]. The interaction 
of nanoparticles with biomolecules and microorganisms is a growing field of research. Many investigations have been performed on the bactericidal effects of nanoparticles and their application in plastics and health [76]. In recent years a rapid increase in microbial strains that are resistant to conventionally used antibiotics has been observed [77, 78]. With the emergence and increase of microbial organisms resistant to multiple antibiotics and the ongoing emphasis on healthcare costs, many scientists are attempting to develop new and effective antimicrobial reagents that microorganisms are not resistant to, and that are cost-effective. Such problems and needs have led to a resurgence in the use of nano-sized antiseptics that may result in broad-spectrum activity and a far lower propensity to induce microbial resistance than antibiotics [79, 80].

Because of their small size nanoparticles may offer additional advantages to the biomedical field through improved biocompatibility. Furthermore, it appears that bacteria are far less likely to acquire resistance against metal nanoparticles, in contrast to other conventional and narrow-spectrum antibiotics. This is attributed to the fact that metals may act on a broad range of microbial targets, and many mutations are required for microorganisms to develop resistance. The shape of the nanoparticles may also influence their activity [65]. Many metals have been used for centuries as antimicrobial agents. Copper, gold, titanium, and zinc in particular have drawn attention, with each one having different properties and spectra of antimicrobial activity $[81,82]$. The broad antibacterial activity of nano-Ag reduces patient infection, dependence on antibiotic use, and associated costs. There is an opportunity for improvement in the areas of stabilising and prolonging the antibacterial effects of nano-Ag coatings for medical applications to prevent infection and inflammation. Finally, with the widespread adoption of nano-Ag, several concerns regarding its toxicity remain and need to be addressed [83]. The use of Ag has been severely limited by the toxicity of Ag ions to humans. However, nanotechnology has aided the production of smaller Ag particles with larger surface area to volume ratios, greater efficacy against bacteria [84], and, more importantly, lower toxicity to humans [85]. The mechanisms underlying the impressive biological properties of nano-Ag are still not sufficiently understood, and therefore are priority candidates for future in vivo research $[86,87]$.

In a study by Freitas et al., the control group had low cadmium, copper, and zinc ion concentrations ( $p>0.05$ ), whereas the ion concentration of $\mathrm{Ag}$ was below the detection limit. In the study group, all the ions showed significant concentrations $10 \mathrm{~min}$ after the placement of a silver solder-containing orthodontic appliance $(\mathrm{p}<0.001)$. The highest mean concentration was for copper $(70.60 \mu \mathrm{g} / \mathrm{L})$ and the lowest mean concentration was for zinc $(0.07 \mu \mathrm{g} / \mathrm{L})$. Comparisons between groups revealed significant differences for copper (all time periods), zinc (10 min, $24 \mathrm{~h}$, and 7 and 30 days), and cadmium (only at $10 \mathrm{~min}$ ). Large amounts of these ions were released, with the highest concentrations observed immediately after the intraoral placement of the appliance [88, 89]. A study by Elshahawy et al. on fixed prosthodontics also confirmed these results [90].
Nano- $\mathrm{TiO}_{2}$ constitutes another class of nanocomposite that has found wide application in orthopaedic and dental implants. However, there are recent reports indicating the induction of cardiac toxicity by these nanoparticles, especially in patients with cardiac disorders. Thus, one must also consider the overall pathophysiological state of the patient prior to the use of these nanoparticles [91]. In summary, with the increased use of inorganic, carbon-based, and non-biodegradable micro/ nanoparticles in the area of bionics, one must not neglect toxicological evaluations to determine their safety with long-term use in order to facilitate their successful admission into the dental market [92].

\section{CONCLUSIONS}

Nanoparticles have come a long way, and have become one of the most effective antibacterial agents as a result of their large surface area-to-volume ratios. They can be used as effective growth inhibitors for various microorganisms. Furthermore, nanoparticles can be modified to achieve enhanced efficacy and make their application possible in various areas, such as in the development of dental and medical biomaterials. However, long-term antibacterial, physical, and clinical effects, along with their impact on living organisms, should be carefully investigated in forthcoming studies.

\section{REFERENCES}

1. Akbari M, Zebarjad SM, Nategh B, Rouhani A. Effect of nano silica on setting time and physical properties of mineral trioxide aggregate. J Endod 2013;39(11):1448-51. doi: 10.1016/j.joen.2013.06.035.

2. Saghiri MA, Godoy FG, Gutmann JL, Lotfi M, Asatourian A, Sheibani N, et al. The effect of $\mathrm{pH}$ on solubility of nano-modified endodontic cements. J Conserv Dent 2014;17(1):13-7. doi: 10.4103/0972-0707.124096.

3. Javidi M, Zarei M, Naghavi N, Mortazavi M, Nejat AH. Zinc oxide nanoparticles as sealer in endodontics and its sealing ability. Contemp Clin Dent 2014;5(1):20-4. doi: 10.4103/0976-237X.128656.

4. Monzavi A, Eshraghi S, Hashemian R, Momen-Heravi F. In vitro and ex vivo antimicrobial efficacy of nano-MgO in the elimination of endodontic pathogens. Clin Oral Investig 2015;19(2):349-56. doi: 10.1007/s00784-014-1253-y.

5. Ahmad Z, Pandey R, Sharma S, Khuller GK. Alginate nanoparticles as antituberculosis drug carriers: formulation development, pharmacokinetics and therapeutic potential. Indian J Chest Dis Allied Sci 2006;48(3):171-6.

6. Kassaee MZ, Akhavan A, Sheikh N, Sodaga A. Antibacterial effects of a new dental acrylic resin containing silver nanoparticles. J Appli Polym Sci 2008;110:1699-3. doi: 10.1002/app.28762.

7. Subba Rao CVS, Vanajasan PP, Chandana VS. Scope of biomaterials in conservative dentistry and endodontics. Trends Biomater Artif Organs 2011;25:75-8.

8. Acosta-Torres LS, Mendieta I, Nuñez-Anita RE, Cajero-Juárez M, Castaño VM. Cytocompatible antifungal acrylic resin containing silver nanoparticles for dentures. Int J Nanomedicine 2012;7:4777. doi: 10.2147/IJN.S32391.

9. Ghaffari T, Hamedi-rad F. Effect of Silver nano-particles on tensile strength of acrylic resins. J Dent Res Dent Clin Dent Prospects 2015;9(1):40-3. doi: 10.15171/joddd.2015.008.

10. Lee WF, Tsao KT. Preparation and properties of nanocomposite hydrogels containing silver nanoparticles by ex situ polymerization. J Appli Polym Sci 2006;100:3653-61. doi: 10.1002/app.23171.

11. Lee $C$, Lee M, Nam K. Inhibitory Effect of PMMA denture acrylic impregnated by silver nitrate and silver nano-particles for Candida albicans. J Korean Chem Soc 2008;52:380-6. 
12. Boldyryeva H, Umeda N, Plaskin QA, Takeda Y, Kishimoto N. Highfluence implantation of negative metal ions into polymers for surface modification and nanoparticle formation. Surf Coat Tech 2005;196:373-7. doi: 10.1016/j.surfcoat.2004.08.159.

13. Casemiro LA, Martins CHG, Pires-de-Souza FC. Antimicrobial and mechanical properties of acrylic resins with incorporated silver-zinc zeolite- Part 1. Gerodontology 2008;25:187-94. doi: 10.1111/j.1741-2358.2007.00198.x.

14. Busscher HJ, Rinastiti M, Siswomihardjo W, Mei HC. The use of nanoparticles to control oral biofilm formation. J Dent Res 2010;89:657-65. doi: $10.1177 / 0022034510368644$.

15. Giertsen E. Effects of mouth rinses with triclosan, zinc ions, copolymer, and sodium lauryl sulphate combined with fluoride on acid formation by dental plaque in vivo. Caries Res 2004;38:430-5. doi: 10.1159/000079623.

16. Pollini M, Russo M, Licciulli A, Sannino A, Maffezzoli A. Characterization of antibacterial silver coated yarns. J Mater Sci - Mater Med 2009;20(11):2361-6. doi:10.1007/s10856-009-3796-z.

17. Chladek G, Mertas A, Barszczewska-Rybarek I, Nalewajek T. Antifungal activity of denture soft lining material modified by silver nanoparticles a pilot study. Int J Mol Sci 2011;12(7):4735-44. doi: 10.3390/ijms12074735.

18. Chladek G, Barszczewska-Rybarek I, Lukaszczyk J. Developing the procedure of modifying the denture soft liner by silver nanoparticles. Acta Bioeng Biomech 2012;14(1):23-9.

19. Chladek G, Kasperski J, Barszczewska-Rybarek I, Żmudzki J. Sorption, solubility, bond strength and hardness of denture soft lining incorporated with silver nanoparticles. Int J Mol Sci 2013;14(1):563-74. doi: 10.3390/ijms14010563.

20. Monteiro DR, Silva S, Negri M, Gorup LF. Antifungal activity of silver nanoparticles in combination with nystatin and chlorhexidine digluconate against Candida albicans and Candida glabrata biofilms. Mycoses 2013;56:672-80. doi: 10.1111/myc.12093.

21. Nam KY, Lee CH, Lee CJ. Antifungal and physical characteristics of modified denture base acrylic incorporated with silver nanoparticles. Gerodontology 2011;29:e413-9. doi: 10.1111/j.1741-2358.2011.00489.x.

22. Gendreau L, Loewy ZG. Epidemiology and etiology of denture stomatitis. J Prosthodont 2011;20(4):251-60. doi: 10.1111/j.1532-849X.2011.00698.X.

23. Wang WG, Sun X, Huang L, Gao Y, Ban JH, Shen LJ, et al. Structure-property relationships in hybrid dental nanocomposite resins containing monofunctional and multifunctional polyhedral oligomeric silsesquioxanes. Int J Nanomedicine 2014;9:841-52. doi: 10.2147/IJN.S56062.

24. Melo M, Cheng L, Zhang K. Novel dental adhesives containing nanoparticles of silver and amorphous calcium phosphate. Dent Mater 2013;29(2):199210. doi: 10.1016/j.dental.2012.10.005.

25. Melo M, Cheng L, Weir MD. Novel dental adhesive containing antibacterial agents and calcium phosphate nanoparticles. J Biomed Mater Res B Appl Biomater 2013;101B:620-9. doi: 10.1002/jbm.b.32864.

26. Zhang XY, Zhang XJ, Huang ZL, Zhu BS, Chen RR. Hybrid effects of zirconia nanoparticles with aluminum borate whiskers on mechanical properties of denture base resin PMMA. Dent Mater J 2014;33(1):141-6. doi: 10.4012/dmj.2013-054.

27. Elsaka SE, Hamouda IM, Swain MV. Titanium dioxide nanoparticles addition to a conventional glass-ionomer restorative: Influence on physical and antibacterial properties. J Dent 2011;39:589-98. doi: 10.1016/j. jdent.2011.05.006.

28. Pinnavia TJ, Beal GW. Polimer clay - nanocomposites. Chichester: John Wiley \& Sons; 2000. p. 3-263.

29. Okamoto M, Morita S, Taguchi H, Kim YH, Kotaka T, Tateyama H. Synthesis and structure of smectic clay/poly(methyl methacrylate) and clay/polystyrene nanocomposites via in situ intercalative polymerization. Polymer 2000;41:3887-90. doi: 10.1016/S0032-3861(99)00655-2.

30. Tabtiang A, Lumlong S, Venables RA. Influence of preparation method upon the structure and relaxation characteristics of poly(methyl methacrylate)/clay composites. Eur Polym J 2000;36:2559-68. doi: 10.1016/ S0014-3057(00)00061-6.

31. Gao Z, Xie W, Hwu JM, Wells L, Pan WP. The characterization of organic modified montmorillonite and its filled PMMA nanocomposite. J Therm Anal Cal 2001;64:467-75. doi: 10.1023/A:1011514110413.

32. Spychaj S, Spychaj T, Sobolewska E, Frączak B, Ey-Chmielewska H, Sniegowska I. The influence of nanofillers on the properties of dental acrylic composites. Eng Biomater 2007;10(62):18-25.

33. Sobolewska E, Spychaj S, Zieliński P, Frączak B, Ey-Chmielewska H. Influence of modified bentonitee addition on acrylic nanocomposite properties. Eng Biomater 2004;7(37):21-7.
34. Segerström S, Sandborgh-Englund G, Ruyter EI. Biological and physicochemical properties of carbon-graphite fibre-reinforced polymers intended for implant suprastructures. Eur J Oral Sci 2011;119:246-52. doi: 10.1111/j.1600-0722.2011.00826.x.

35. Östman PO, Hupalo M, Del Castillo R. Immediate provisionalization of nanotite implants in support of single-tooth and unilateral restorations: one-year interim report of a prospective, multicenter study. Clin Implant Dent Relat Res 2009;12:e47-e55. doi: 10.1111/j.1708-8208.2009.00166.x.

36. Göncü Basaran E, Ayna E, Vallittu PK, Lassila LV. Load-bearing capacity of handmade and computer-aided design-computer-aided manufacturing-fabricated three-unit fixed dental prostheses of particulate filler composite. Acta Odontol Scand 2011;69(3):144-50. doi: 10.3109/00016357.2010.545034.

37. Qiu L, Chen Y, Yang Y, Xu L, Liu X. A study of surface modifications of carbon nanotubes on the properties of polyamide 66/multiwalled carbon nanotube composites. J Nanomater 2013;2013:Article ID 252417. doi: $10.1155 / 2013 / 252417$.

38. Uzun G, Keyf F. The effect of fiber reinforcement type and water storage on strength properties of a provisional fixed partial denture resin. J Biomater Appl 2003;17(4):277-86. doi: 10.1177/0885328203017004003.

39. Rached RN, Souza EM, Dyer SR, Ferracane JL. Dynamic and static strength of an implant-supported overdenture model reinforced with metal and nonmetal strengtheners. J Prosthet Dent 2011;106(5):297-304. doi: 10.1016/S0022-3913(11)60134-0.

40. Stafford GD, Hugget R, MacGregor AR, Graham J. The use of nylon as a denture-base material. J Dent 1986;14:18-22. doi: 10.1016/03005712(86)90097-7.

41. Waltimo T, Brunner TJ, Vollenweider M. Antimicrobial effect of nanometric bioactive glass 45S5. J Dent Res 2007;86:754-7. doi: 10.1177/154405910708600813.

42. Zhao J, Xie D. Effect of nanoparticles on wear resistance and surface hardness of a dental glass-ionomer cement. J Compos Mater 2009;43:2739-51. doi: 10.1177/0021998309345341.

43. Sumita M, Shizuma T, Miyasakaand K, Ishikawa K. Effect of reducible properties of temperature, rate of strain, and filler content on the tensile yield stress of nylon 6 composites filled with ultrafine particles. J Macromol Sci B Phys 1983;22:601-18. doi: 10.1080/00222348308224779.

44. Kuo MC, Tsai CM, Huang JC, Chen M. PEEK composites reinforced by nanosized SiO2 and Al203 particulates. Mater Chem Phys 2005;90:185-95. doi: 10.1016/j.matchemphys.2004.10.009.

45. Protopapa P, Kontonasaki E, Bikiaris D, Paraskevopoulos KM. Reinforcement of a PMMA resin for fixed interim prostheses with nanodiamonds. Dental Mater J 2011;30(2):222-31. doi: 10.4012/dmj.2010-135.

46. Castranova V, Schulte PA, Zumwalde RD. Occupational nanosafety considerations for carbon nanotubes and carbon nanofibers. Acc Chem Res 2013;19;46(3):642-9. doi: 10.1021/ar300004a.

47. Lam CW, James JT, McCluskey R. A review of carbon nanotube toxicity and assessment of potential occupational and environmental health risks. Crit Rev Toxicol 2006;36(3):189-217. doi: 10.1080/10408440600570233.

48. Murray AR, Kisin ER, Tkach AV. Factoring-in agglomeration of carbon nanotubes and nanofibers for better prediction of their toxicity versus asbestos. Part Fibre Toxicol 2012;10(9):10. doi: 10.1186/17438977-9-10.

49. Chatterjee N, Eom HJ, Choi J. A systems toxicology approach to the surface functionality control of graphene-cell interactions. Biomaterials 2014;35(4):1109-27. doi: 10.1016/j.biomaterials.2013.09.108.

50. Feng L, Liu Z. Graphene in biomedicine: opportunities and challenges. Nanomedicine 2011;6(2):317-24. doi: 10.2217/nnm.10.158.

51. Li Y, Feng L, Shi X, Wang X, Yang Y, Yang K, et al. Surface coating-dependent cytotoxicity and degradation of graphene derivatives: towards the design of non-toxic, degradable nano-graphene. Small 2014;10(8):1544-54. doi: 10.1002/smll.201303234.

52. He J, Zhu X, Qi Z, Wang C, Mao X, Zhu C, et al. Killing dental pathogens using antibacterial graphene oxide. ACS Appl Mater Interfaces 2015;7(9):560511. doi: 10.1021/acsami.5b01069.

53. Kulshrestha S, Khan S, Meena R, Singh BR, Khan AU. A graphene/zinc oxide nanocomposite film protects dental implant surfaces against cariogenic Streptococcus mutans. Biofouling 2014;30(10):1281-94. doi: 10.1080/08927014.2014.983093.

54. Lee JH, Shin YC, Jin OS, Kang SH, Hwang YS, Park JC, et al. Reduced graphene oxide-coated hydroxyapatite composites stimulate spontaneous 
osteogenic differentiation of human mesenchymal stem cells. Nanoscale 2015;7(27):11642-51. doi: 10.1039/c5nr01580d.

55. Kanayama I, Miyaji H, Takita H. Comparative study of bioactivity of collagen scaffolds coated with graphene oxide and reduced graphene oxide. Int J Nanomedicine 2014;9:3363-73. doi:10.2147/IJN.S62342.

56. Kohgo T, Yamada Y, Ito K, Yajima A, Yoshimi R, Okabe K, et al. Bone regeneration with self-assembling peptide nanofiber scaffolds in tissue engineering for osseointegration of dental implants. Int J Periodontics Restorative Dent 2011;31(4):e9-16.

57. Li H, Yang L, Dong X, Gu Y, Lv G, Yan Y. Composite scaffolds of nano calcium deficient hydroxyapatite/multi-(amino acid) copolymer for bone tissue regeneration. J Mater Sci - Mater Med 2014;25(5):1257-65. doi: 10.1007/s10856-014-5164-x.

58. Kato E, Sakurai K, Yamada M. Periodontal-like gingival connective tissue attachment on titanium surface with nano-ordered spikes and pores created by alkali-heat treatment. Dent Mater 2015;31(5):e116-30. doi: 10.1016/j.dental.2015.01.014.

59. Frost PM. An audit on the placement and replacement of restorations in a general dental practice. Prim Dent Care 2002;9:31-6.

60. Lara HH, Ayala-Nuñez NV, Ixtepan-Turrent L, Rodriguez-Padilla C. Mode of antiviral action of silver nanoparticles against HIV-1. J Nanobiotechnology 2010;8:1. doi: 10.1186/1477-3155-8-1

61. Borkow G, Lapidot A. Multi-targeting the entrance door to block HIV-1. Curr Drug Targets Infect Disord 2005;5:3-15. doi: 10.2174/1568005053174645.

62. Al-Jabri AA, Alenzi FQ. Vaccines, virucides and drugs against HIV/ AIDS: hopes and optimisms for the future. Open AIDS J 2009;3:1-3. doi: $10.2174 / 1874613600903010001$.

63. Giertsen E. Effects of mouth rinses with triclosan, zinc ions, copolymer, and sodium lauryl sulphate combined with fluoride on acid formation by dental plaque in vivo. Caries Res 2004;38:430-5. doi: 10.1159/ 000079623.

64. Pollini M, Russo M, Licciulli A, Sannino A, Maffezzoli A. Characterization of antibacterial silver coated yarns. J Mater Sci - Mater Med 2009;20(11):2361-6. doi: 10.1007/s10856-009-3796-z.

65. Chladek G, Mertas A, Barszczewska-Rybarek I, Nalewajek T. Antifungal activity of denture soft lining material modified by silver nanoparticles - a pilot study. Int J Mol Sci 2011;12(7):4735-44. doi: 10.3390/ijms 12074735 .

66. Chladek G, Barszczewska-Rybarek I, Lukaszczyk J. Developing the procedure of modifying the denture soft liner by silver nanoparticles. Acta Bioeng Biomech 2012;14(1):23-9.

67. Huang Z, Sargeant TD, Hulvat JF, Mata A, Bringas P Jr, Koh CY, et al. Bioactive nanofibers instruct cells to proliferate and differentiate during enamel regeneration. J Bone Miner Res 2008;23:1995-2006.

68. Lee SJ, Atala A. Scaffold technologies for controlling cell behavior in tissue engineering. Biomed Mater 2013;8(1):010201. doi: 10.1088/17486041/8/1/010201.

69. Moioli EK, Clark PA, Xin X, Lal S, Mao JJ. Matrices and scaffolds for drug delivery in dental, oral and craniofacial tissue engineering. Adv Drug Deliv Rev 2007;59:308-24.

70. Rim NG, Shin CS, Shin H. Current approaches to electrospun nanofibers for tissue engineering. Biomed Mater 2013;8(1):014102. doi: 10.1088/17486041/8/1/014102.

71. Kasaj A, Willershausen B, Reichert C, Rohrig B, Smeets R, Schmidt M. Ability of nanocrystalline hydroxyapatite to promote human periodontal ligament cell proliferation. J Oral Sci 2008;50:279-85.

72. Inamdar NK, Borenstein JT. Microfluidic cell culture models for tissue engineering. Curr Opin Biotechnol 2011;22:681-9.
73. Ennett AB, Kaigler D, Mooney DJ. Temporally regulated delivery of VEGF in vitro and in vivo. J Biomed Mater Res A 2006;79:176-84.

74. Kohli P, Martin C. Smart nanotubes for biomedical and biotechnological applications. Drug News Perspect 2003;16:566-73.

75. Singaravelu G, Arockiamary JS, Ganesh Kumar V, Govindaraju K. A novel extracellular synthesis of monodisperse gold nanoparticles using marine alga, Sargassum wightii Greville. Colloids Surf B Biointerfaces 2007;57:97101. doi: 10.1016/j.colsurfb.2007.01.010.

76. Zuhuang J. Bactericidal nanosilver cloth and its making process and use. Patent number CN 1387700. 2003.

77. Goffeau A. Drug resistance: the fight against fungi. Nature 2008;452:5412. doi: $10.1038 / 452541$ a.

78. Jones SA, Bowler PG, Walker M, Parsons D. Controlling wound bioburden with a novel silver-containing Hydrofiber dressing. Wound Repair Regen 2004;12:288-94. doi: 10.1111/j.1067-1927.2004.012304.x.

79. Stoimenov PK, Klinger RL, Marchin GL, Klabunde KJ. Metal oxide nanoparticles as bactericidal agents. Langmuir 2002;18:6679-86. doi: 10.1021/ la0202374.

80. Pal S, Tak YK, Song JM. Does the antibacterial activity of silver nanoparticles depend on the shape of the nanoparticle? A study of the gram-negative bacterium Escherichia coli. Appl Environ Microbiol 2007;27:1712-20. doi: 10.1128/AEM.02218-06.

81. Giertsen E. Effects of mouth rinses with triclosan, zinc ions, copolymer, and sodium lauryl sulphate combined with fluoride on acid formation by dental plaque in vivo. Caries Res 2004;38:430-5. doi: 10.1159/000079623.

82. Chaloupka K, Malam Y, Seifalian AS. Nanosilver as a new generation of nanoproduct in biomedical applications. Trends Biotechnol 2010;28:5808. doi: 10.1016/j.tibtech.2010.07.006.

83. You C, Han C, Wang X. The progress of silver nanoparticles in the antibacterial mechanism, clinical application and cytotoxicity. Mol Biol Rep 2012;39(9):9193-201. doi: 10.1007/s11033-012-1792-8.

84. Arora S, Jain J, Rajwade JM, Paknikar KM. Interactions of silver nanoparticles with primary mouse fibroblasts and liver cells. Toxicol Appl Pharmacol 2009;236:310-8. doi: 10.1016/j.taap.2009.02.020.

85. Asharani PV, Lian Wu Y, Gong Z, Valiyaveettil S. Toxicity of silver nanoparticles in zebrafish models. Nanotechnology 2008;19(25):255102. doi: 10.1088/0957-4484/19/25/255102.

86. Asharani PV, Mun GLK, Hande MP, Valiyaveettil S. Cytotoxicity and genotoxicity of silver nanoparticles in human cells. ACS Nano 2009;3(2):279. 90. doi: 10.1021/nn800596w.

87. Melnik EA, Yu P, Buzulukov V, Demin F, Demin VA, Gmoshinski IV, et al. Transfer of silver nanoparticles through the placenta and breast milk during in vivo experiments on rats. Acta Naturae 2013;5(3):107-15.

88. Freitas MPM, Oshima HMS, Menezes LM. Release of toxic ions from silver solder used in orthodontics: An in-situ evaluation. Am J Orthod Dentofacial Orthop 2011;140(2):177-81. doi: 10.1016/j.ajodo.2010.06.024.

89. Freitas MPM, Oshima HMS, Menezes LM. Cytotoxicity of silver solder employed in orthodontics. Angle Orthod 2009;79:939-44. doi: 10.2319/101108-530.1.

90. Elshahawy W, Watanabe I, Koike M. Elemental ion release from four different fixed prosthodontic materials. Dent Mater 2009;25:976-81. doi: 10.1016/j.dental.2009.02.004.

91. Sha B, Gao W, Wang S, Li W, Liang X, Xu F, et al. Nano-titanium dioxide induced cardiac injury in rat under oxidative stress. Food Chem Toxicol 2013;58:280-8.

92. Xie D, Weng Y, Guo X, Zhao J, Gregory RL, Zheng C. Preparation and evaluation of a novel glass-ionomer cement with antibacterial functions. Dent Mater 2011;27:487-96. doi: 10.1016/j.dental.2011.02.006.46. 